\title{
Dialog Pamungkas Alquran: Suatu Rekonstruksi Hukum (Syariah)
}

\author{
dan Ralitas Kehidupan
}

Oleh: Drs. H. Danni Ramadhani, M.A.

ramdhani789@gmail.com

\begin{abstract}
Abstraksi
Tidak ada kitab agama yang sangat lengkap di bumi ini selain Alquran. Wahyu Allah ini adalah sumber hukum Islam utama sebelum yang lainnya (Hadits dan ijtihadArrakyu). Alquran memuat kaidah hukum fundamental yang harus dikaji lebih lanjut. Dengan melihatnya sebagai sumber hukum, menjadikan umat Islam memiliki pranata hukum paling tua di dunia. Jauh lebih tua sebelum hukum positif buatan barat lahir di dunia. Konon, menurut guru besar agama Islam di Universitas Indonesia, Prof. Dr. Azhari, legislator Perancis pernah belajar tentang beberapa prinsip hukum (waris, misalnya) dari para mufti Mesir. Hal ini yang menjadikan adanya kemiripan dalam masalah legitimatie portie wasiat dan orang yang terlarang mendapatkan warisan karena membubuh pewarisnya (mawani'ul irtsi).
\end{abstract}

Kata kunci: Alquran, Rekonstruksi Hukum (syariah)

\section{PENDAHULUAN}

Hukum Islam memang berbeda dengan Barat lantaran hukum barat bersifat sekular, sedangkan hukum Islam erat kaitannya dengan akidah akhlak dan ibadah itu sendiri. Namun hukum Islam (syariah) mengandung dua hal pokok, yakni yang mengandung ikhwal ibadah mahdhoh yang bersifat tertutup dan segala urusan muamalah yang bersifat terbuka.

Selain dikenal dengan istilah al ahkamul Khamsah (hukum yang lima) yang terdiri dari wajib, sunnah, jaiz, haram dan makruh dalam lapangan taklifiyyah, juga dikenal hukum wadhi'iy yang terbentuk karena sebab, syarat dan

\footnotetext{
${ }^{5}$ Dosen Program Studi Sekretari Fakultas Ekonomi Universitas Pamulang
} 
halangan. Sedangkan pembentukan hukum berkaitan pula dengan maqashidus syariah.

Kitab suci Al Alquran memang beda. Kandungannya komprehensif, sempurna, aplikasinya universal, melewati batasan waktu dan wilayah. Dibanding kitab suci lain, kitab ini mengandung dan menjadi sumber utama hukum Islam, sumber utama keyakinan (akidah), sumber ubudiyah dan muamalah (pergaulan sosial) serta sumber akhlaq. Siti Aisyah mengatakan, akhlaq Nabi Muhammad, adalah seluruh isi Al Alquran itu sendiri. Sementara hukum segala urusan kehidupan berpangkal tolaj dari Alquranul Karim. Meski akidah menjadi pucuk utama yang mengalirkan syariah dan akhlak, toh syariah (hukum Islam) adalah jalan hidup muslim yang memuat ketetapan allah dan Rasulnya bagi kehidupan ini, baik berupa larangan maupun perintah. ${ }^{i i}$ Syariah adalah norma hukum dasar yang ditetapkan Allah berdasarkan iman (akidah) yang berkaitan dengan akhlak,

\section{PEMBAHASAN}

\section{Alquran Itu Kitab Suci Istimewa}

Orientalis terkemuka yang dianggap paling objektif dan kredibel Prof. H. A. R. Gibb dalam 'Mohammedanism' berkali-kali mengatakan, alquran itu kitab suci istimewa, bukti kuat tentang mukjizat, iii ungkapnya. Muatan isinya meliputi kisahkisah masa lalu, berita-berita tentang zaman mendatang benih-benih pengetahuan, akidah, syariah dan akhlak. Mayoritas konten Alquran berbicara soal muamalah. Bahkan ada yang mengatakan, kuantitas dalam Alquran mengenai muamalah nyaris sebesar 70 persen yang berarti urusan-urusan sosial ( hablum minannas) yang bukan soal ibadah. Ada lagi yang mengatakan, bahwa komposisi isi kitab suci yang namanya beragam ini adalah tentang Aqidah sebesar 2\%, akhlak sebesar 1\%, ibadah sebesar 2\% dan Mu'amalah sebesar 95\%. Sehingga kitab suci ini dianggap menjadi bukti relevan, bahwa Islam bukan agama dogma yang melulu doktrin theologis, tetapi agama din (agama itu sendiri), dunya (materialism) dan daulah (kekuatan - politik), dan disitulah konkritnya Alquran sebagai rahmatan lil alamin. Salah satu testimony yang jelas, satu ayat yang paling panjang dalam alquran ternyata membahas masalah hutang piutang di 
antara manusia (lihat QS. Al-Baqarah: 282). Tetapi khusus menyangkut hukum amaliah, yaitu hukum-hukum mengenai perbuatan, perjanjian dan hubungan kerja sama antara sesama manusia dan hubungan dengan allah tidak banyak jumlahnya dibanding keseluruhan ayat yang berjumlah 666 buah. Dijelaskan Abdul Wahab Khallaf, ayat-ayat hukum ibadah hanya berjumlah 40 ayat, hukum-hukum mengenai muamalah berjumlah 228 ayat, hingga jumlah keseluruhannya hanya sekitar 5,8\% saja.

Memang ada anggapan seolah-olah Aqidah pasti menempati urutan pertama (paling tinggi persentasenya). Akan tetapi terbukti tidak. Turunan (deviasi) Alquran diejawantahkan dalam banyak kitab muamalah. Bahkan Alkhawarizmi yang ahli matematika dan astronomi itu, penemun angka 0 , penemu bulatnya bumi dan pembuat peta dunia pertama, dianggap ulama yang berhasil mengembangkan Alquran lebih lanjut. Begitu pula Ibnu Sina (Avessina) mengembangkan Alquran dari sisi kedokteran. Islam juga tergas menyebut hukum mu'amalah seperti jual beli, sewa-menyewa, gadai, dan lain sebagainya, adalah halal dan diperbolehkan sebagaimana asal hukum segala sesuatu yang ada di bumi itu halal dan diperbolehkan, kecuali ada dalil yang melarangnya. Ini adalah pendapat jumhur ulama, madzhab maliki, mazhab Syafi'i, madzhab Hanbali, dan sebagian besar ulama madzhab Hanafi, bahkan Ibnu Rajab mengatakan, "sebagaimana ulama mengatakan ini adalah kesepakatan para ulama." Hingga kini, kaum santri di berbagai pesantren diajarkan Ilmu Falak yang sesungguhnya ilmu astronomi, seperti di ITB, atau Ilmu Baladagh yang juga diajarkan di fakultas sastra. Tetapi mereka tetap menyebutnya ilmu agama.

Kitab-ktab fiqh muamalah, dianggap derivasi alquran paling kontenstual. Kitab Al-Amwal yang dikarang Abu Ubaid, kitab Al-Kharaj karangan Abu Yusuf atau tulisan lain Karya Ibn Chaldun serta buku-buku baru yang membahas masalah Ekonomi Syariah seolah memberikan kesadaran baru masyarakat dunia tentang tidak becusnya ekonimi kapitalis mengangkat harkat derahat dan perlunya kehadiran ekonomi syariah (Islam) dalam mengambil alih peran pokok mensejahterakan umat. Banyak pihak menggali Alquran sebagai alternative menjawab kebutuhan terhadap tantangan zaman.

Guru besar Hukum Islam dari Universitas Indonesia, Prof. H. Mohammad Daud Ali, SH mengatakan, konsep "hukum" dalam Alquran, jauh lebih luas dari konsep 
hukum menurut hukum Barat. Sebab selain kaidah yang mengatur hubungan manusia dengan Allah (Akidah) serta manusia dengan manusia atau makhluk lainnya, hukum Islam juga harus mengandung muatan nilai-nilai yang dipengaruhi oleh moral atau akhlak. Menurutnya, konsep hukum menurut AlAlquran adalah all comprehensive: sesuai dengan sifat penciptanya. Jadi tentu saja berbeda dengan konsep hukum yang disampaikan Barat yang sifatnya materialistik, sekuristik, memisahkan hukum dengan agama dan kesusilaan, "hukum dalam Alquran harus terjalin berkelindan dengan iman dan akhlak." Menjadi sebuah pertanyaan, mengapa konsep muamalah, seperti jual beli, bisa begitu detil di bahas didalamnya, karena Islam mengaturnya menjadi suatu hukum, sehingga terasa disiplin, akurat dan humanis. Betapa tidak, buyu (jual beli) dalam Alquran adalah bersifat ta'awun (tolong menolong), bukan sekedar bisnis itu sendiri.

Namun menyebut wilayah muamalah hanya sekedar jual beli, hal ini terlalu menyederhanakan persoalan. Abdul Wahab Khallaf yang tegas menyebutnya sebagai "hukum", merilis lebih jauh muamalah sebagai konsep dalam mengatur hubungan manusia dengan manusia dalam segala dimensinya, termasuk perdata, pidana, tata Negara, hukum internasional, hukum ekonomi keuangan, bahkan hukum acara.

\section{Kesadaran Baru Kaum Intelektual}

Gerakan kembali kepada Alquran, bukan sekedar reaksi biasa, apalagi sekedar anti bidah. Tetapi bukti kejenuhan banyak pihak dalam menghadapi tantangan zaman. Tepatnya, ketidakpuasan. Di Indonesia, gerakan itu dimotori kaum cerdik pandai (intelektual) dari berbagai kalangan. Dihingar-bingarkan anak-anak muda kreatif di pengajian masjid-masjid yang berlokasi di lingkungan perguruan tinggi, semisal masjid Salman ITB, masjid Arif Rahman di Universitas Indonesia, dll. Mereka getol mempertanyakan kembali kedalaman Alquran (baca: tafsir) dalam realitas kehidupan. Kemudian tumbuh berkembang menjadi organisasi sempalan, hingga tumbuh berkembang menjadi semacam sekte atau

aliran. Bahkan ciri khas kaum jenggotan dan kelompok agamis mengalahkan formalisme kaum santri dengan ciri khas kopiah dan sarungan pada dekade 80-an. 
Mereka menamakan dirinya kaum puritan yang mengembalikan Alquran dan sunnah kepada umat yang sesungguhnya. Alasan mereka: Umat sekarang banyak menyimpang dari Alquran dan Hadits, Khurafat mewabah, bid'ah berserakan. Syakib Arsalan, penulis buku "Limadza taakhkharal musliman wa taqaddama ghairuhum?" menyatakan, Orang Non Islam maju karena meninggalkan kitab sucinya, orang Islam justeru mundur lantaran meninggalkan kitab sucinya. Penyataan Syakib cukup beralasan.

Kesadaran massif kaum intelektual terhadap kitab suci Alquran, adalah masalah serius, bahwa kegelisahan umat terhadap persoalan dunia sekarang harus dijawab oleh dalil-dalil yang komprehensif dan representatif. Untuk itu harus ada upaya lebih lanjut agar teks-teks Alquran dapat difahami secara kontekstual. Upaya kearah itu dicoba dijawab dengan hadirnya berbagai tafsir dengan metoda baru yang pas untuk realitas kekinian. Misalnyam dengan menghadirkan pendalaman materi untuk tafsir kontekstual, tafsir hermeunetika, takwil, dll. yang pada masa lalu cukup saja literal dan konvensional.

DR. Charles Francis Potter menulis dalam The Faith Men Live By, bahwa Bibel, mungkin buku yang paling banyak laku. Tetapi hampir 250 juta pengikut Nabi Muhammad membaca atau menghafal bagian-bagian yang panjang darinAlquran lima kali sehari, setiap hari selama hidupnya sejak mereka dapat bercakap.viii Sedangkan Basanta Coomar Bose mengatakan: "Maka tidak ada kesempatan bagi setiap pemalsuan yang membedakan dia dari hampir seluruh kitab-kitab agama yang penting zaman dahulu... ix Para pemuja Alquran meyakini benar, bahwa Alquran adalah sumber kehidupan segala zaman. Membacanya pahala, mendengarkan bacaannya pahala, mendalaminya pahala, apalagi melaksanakan isinya, pasti berpahala. Alquran dilagukan, Alquran diperlombakan.

Soal perlunya menggairahkan kembali pendalaman makna teks-teks Alquran, disampaikan dalam Mukernas Ulama Alquran yang diselenggarakan Lajnah Pentashih Mushaf Alquran Balitbang Diklat Kementrian Agama Mei 2013 lali di Serang, Banten. Kegiatan itu yang mengingatkan perlunya agenda 
mendialogkan teks dengan realita, adalah substansi misi Alquran itu sendiri. Kemukjizatan Alquran paling besar terletak pada kemampuannya menyapa realitas dengan solusi. Turunnya kitab ini secara bertahap mengikuti peristiwa yang terjadi seperti terdokumentasikan dalam asbabun-nuzul- merupakan upayanya untuk berdialog dengan realita. Masalahnya, sampai kaan pemahaman itu direkam dengan baik oleh umat ini?

Agenda mendialogkan teks Alquran dengan realita, sejatinya dilakukan pada sisi pendalaman materi dan perumusan metodologi tafsir alternatif. Upaya menemukan metode tafsir alternatif seiring dengan semangat mendialogkan teks dan realita, serta mengikuti perkembangan realita yang terus berubah secara dinamis. Dengan selesainya wahyum maka berhenti pula turunnya teks. Sementara realita terus berkembang seiring dengan perjalanan zaman. Itu sebabnya, ijtihad mutlak dibutuhkan dalam menjembatani teks Alquran dan realita. Dengan demikian, metode tafsir alternatif dihadirkan sejatinya memberikan ruang yang luas bagi ijtihad dan qiyas, ruang yang tidak diberikan cukup luas oleh metode tafsir yang ada. Selain itu semua memahami bahwa Alquran itu sendiri dilengkapi tafsirannya oleh Hadits. Dan bersama Hadits, Alquran bertindak sebagai sumber hukum utama yang duduk lebih tegak, ditambah lagi dengan ijtihad yang sudah diformulasikan dalam bentuk Istihsan, Istishab, Maslahatul Mursalah dan kemudian 'Uruf (tradisi).

Tafsiran yang keliru melahirkan anggapan yang salah terhadap ajaran Islam. Setidaknya, ada anggapan seolah Islam itu anti modernisasi, anti kekinian. Prof. Mohammad Daud Ali menyampaikan pandangannya, bahwa kesalahpahaman terhadap Islam disebabkan banyak hal. Namun yang relevan adalah dalam kajian ini, yakni (1) salah memahami ruang lingkup ajaran Islam, (2) salah menggambarkan kerangka dasar ajaran Islam, dan (3) salah menggunakan methoda mempelajari Islam. $\mathrm{X}$

Sejarah kemunculan metode tafsir sebagaimana dikenal seperti ini -seperti dengan apik diulas dalam 'al-Bayinah fit-Tafsir al-Maudhu'i karya al-Fatmawi'-sesungguhnya juga sejarah penemuan tak henti terhadap metode tafsir baru. Sebagai contoh, metode tafsir tematik (maudhu'i) lahir untuk menyempurnakan 
metode tafsir tahlili dan dalam rangka memenuhi kebutuhan mendesak terhadap solusisolusi Alqurani. Hal ini tentu tidak dimaksudkan untuk membangun kembali system peribadatan baru yang sesuai dengan kebutuhan mutakhir. Karena bila hal ini diakomodasi, dapat terjerumus ke dalam pusaran bid'ah (modernisasi) yang disepakati, bahwa masalah ibadah (pokok/mahdhoh) sudah final (tertutup).

Di area wilayah fiqih muamalah, perinciannya terbuka untuk ijtihad, selama memenuhi syarat untuk menjadi mujtahod, termasuk dalam mengelaborasi lebih lanjut kandungan ayat Alquran. Karena itu dengan mempertimbangkan beberapa prinsip, perumusan metode tafosr alternative baru, adalah dimungkinkan. Pertama, banyak ayat Alquran yang memiliki multilevel makna. Sebuah riwayat yang disampaikan Abu Nu'aim dan lainnya dari Ibn 'Abbas (w 68 H/689 M) menyatakan, Alquran memiliki beberapa sisi dan makna (dzul-wujuh). Menurut sebagian ulama, setiap ayat mengandung 60.000 pemahaman, bahkan---- menurut ulama lain - 70.200 karena setiap kata (didalamnya) adalah sebuah pengetahuan, dan kemudian (jumlah) itu dapat berlipat empat, karena setiap kata mempunyai aspek lahir, batin, awal, dan akhir. Selama ini metode tafsir yang ada lebih banyak berorientasi pada makna lahir/eksoterik ayat, sedangkan makna batin/esoterisnya belum maksimal digali, situasi yang menyebabkan suatu teks terkesan memiliki makna terbatas. Bila Alquran diibaratkan kekayaan laut, kita baru mengeksplorasi kekayaan di permukaan laut, sedanhkan yang ada di dasar laut--- apalagi dibawah dasarnya--- belum tergali secara maksimal. Kedua, dengan menggunakan metode takwil - satu alat yang dapat digunakan untuk menyelami kandungan makna Alquran yang tersimpan di balik teks sebuah ayat. Tradisi pemanfaatan takwil secara luas oleh para sufi dan filosop Muslim sebaiknya tidak dinilai lagi sebagao tafsir kirim tetapi dinilai sebagai terobosan yang baik untuk ditiru dalam konteks mengeksplorasi makna-makna ayat.

\section{Alquran Final dan Silabus Baru Pesantren}

Saat ini, teks Alquran dapat dikatakan telah final (QS Almaidah ayat 3).. sebagaimana dikatakan di atas, wahyu telah usai, sekalipun mungkin tugas Malaikat Jibril sesudah itu masih bersifat Debatable, karena ada yang bilang bisa jadi berperan dalam konteks lain. Dalam dogma theologis, semua umat harus 
tunduk kepada kesucian Alquran sebagai salah satu Rukun Iman dari Rukum Iman yang enam. Pertanyaannya, bagaimana cara ketundukan manusia kepada Alquran sebagai sumber ajaran hidup universal di zaman yang terus berubah. Masuk akal jika kitab berbahasa Arab ini tidak akan memberi manfaat yang signifikan jika tidak diselami lebih dalam oleh manusia. Manusialah yang harus berinisiatif melakukan interaksi dam dialog dengan Alquran untuk menggali informasi yang akurat di dalamnya.

Di Indonesia, proses dialog dengan Alquran yang paling intensif selama ini dilakukan melalui system pembelajaran Islam di berbagai pesantren (Islamic boarding school) hingga perguruan tinggi Islam (misalnya, Universitas Islam Negeri - UIN atau Institut Agama Islam Negeri - IAIN). Menurut data Direktorat Pendidikan Diniyah dan Ponondok Pesantren, Ditjen Pendidikan Islam, Kementrian Agama RI, ada kurang lebih 17 ribu buah pesantren di Indonesia dalam berbagai tipe, menyebar sejak Pulau Jawa hingga Papua. Sebagai lembaga pendidikan tertua sejak sebelum penjajahan Belanda, pasti sudah jutaan alumninya yang menjadi prominent person di berbagai lembaga pendidikan, kementrian bahkan politisi dan pimpinan negeri ini. Abdurrahman Wahid, mantan Presiden RI, misalnya adalah putera pendiri dan alumni pokok pesantren di Jawa Timur.

Di luar system pendidikan formal dan informal, masyarakat Indonesia juga memiliki budaya oengajian Alquran yang bersifat non formal di majelis-majelis taklim di seluruh negeri. Umat Islam tanpa memandang usia dan latar belakang ekonomi maupun pendidikan formalnya, duduk bersimpuh dibimbing seorang fasilitator yang menghadirkan diskusi kecil dari makna literal, semantik, maksud untrinsik maupun ekstrinsik dari ayat-ayat aqidah, syariah, mutasyabihat, hingga ayat kauniyah Alquran. Meskipun penelisikan itu terasa kurang mendalam, akan tetapi telah menjadi raw model yang baik bagi dunia dalam peradaban modern.

Setidaknya, ada legalitas formal yang bersifat relijius bagi setiap tudingan, bahwa dunia mengarah kepada peradaban sekularisme. Tapi tudingan itu menjadi tidak berlaku bagi Indonesia. Istilahnya, modernisasi dan materialism, bahkan hedonisme silahkan terus berjalan,namun masyarakat Indonesia telah memiliki barrier yang kuat berkat pengajian-pengajian tersebut. Meskipun model dialog- 
kalau boleh disebut demikian - demikian dengan Alquran masih bersifat kulitnya saja, belum yang beyond the next.

Menggali beyond the next, adalah tantangan nyata yang dihadapi para pengajar, penggali Alquran dewasa ini. Beberapa variable berikut dapat direnungkan untuk ditindak-lanjuti. Pertama, hukum islam (apalagi yang sifatnya muamalah) harus terus dipandang sebagai sesuatu yang terbuka (ijtihadiy). Tidak tertutup. Kajian teks jangan dibuat sebagai sesuatu yang tabu. Toh dalam khasanah tafsir yang beraneka ragam, dikenal nama mufassir fundamentalis ala Sayyid Qutb, yang rasionalis ala Ar-Razi, yang tradisionalis ala Ibnu Katsir, atau yang modernis ala Muhammad Abduh. Artinya, ada keragaman. Ada ide, misalnya, untuk mengembangkan tafsir Alquran yang bersifat lokal untuk Indonesia. Indonesia memang terasa spesal dibanding Negara lain di dunia.

Tantangannya khas, unik dan perlu treatment khusus untuk memahaminya berdasarkan realitas kehidupan kita yang terus berubah. Ayat tentang adanya sumber manusia yang berasal dari lelaki dan perempuan serta keanekaragaman bangsa (Q-S 46, Al Hujurot ayat 13), menjadi pas dalam konteks indonesia. Kedua, hukum Islam harus terus direkonstruksi dan didalami dengan tekun. Agar ada proses pengertian dan akulturasi antara ajaran Alquran ini dengan realitas kehidupan kita yang tidak selalu sama dengan waktu ayat demi ayat ini diturunkan. Ada tudingan pada sejumlah tafsir ayat tertentu dianggapnya konotatif, identik dengan budaya Arab. Misalnya, poligami yang diintrodusir oleh surat Annisa ayat 3 itu berangkat dari $u$ 'ruf atau ada konsensus budaya Arab dengan wahyu Tuhan.

Poligami itu pada awalnya budaya orang Arab. Pemahaman itu tetap trendi hinggga kini pada segelintir orang. Namun bagi kaum terpelajar baru, ayat tersebut berhasil direnstruksi, bahwa pernikahan Islam itu bersifat 'monogamis'. Bukan poligamis. Dengan demikian seharusnya begitulah bahwa hukum Islam selalu punya konsensus dengan keadaan zaman dan masyarakat, atau hukum berjalan beriring dengan situasi dan kondisi umatnya. Selama ini, orang Arab $m$ enganggap wajar bagi pria untuk memperistri banyak wanita dan memiliki selir lebih banyak lagi. Namun Alquran sendiri melakukan perubahan sosial 
sebagaimana dilansir dalam surat An Nisa agar pria memperistri maksimal empat wanita saja, itu pun diembel-embeli dengan prasyarat yang tidak mudah: kalau sang pria bisa berlaku adil. Berdasarkan hal ini, terlihat semangat kesetaraan gender dan ras untuk menjadi agenda yang cukup penting dalam Alquran, meskipun belum terselesaikan dalam proses keberangsurannya.

Rekonstruksi hukum Islam penting, terutama bila melihat pada latar belakang budaya apa proses penurunan ayat demu ayat ini terjadi. Ketiga, untuk itu para mufassir, pengajar atau penggali Alquran harus terus meningkatkan pengetahuannya dan terus memantau perkembangan sekelilingnya. Tidak masalah bila mufassir Alquran itu ahli tentang astronomi, misalnya. Sehingga ketika menjelaskan lapisan bumi dan langit, atau penciptaan alam semesta, dapat dijelaskan secara mendalam. Dengan demikian, teks-teks Alquran itu akan selalu nampak mampu menjawab tantangan zaman. Keempat, agar produk hukum itu tidak diragukan keabsahannya dan dapat segera diendorse oleh para users (umat), maka model ijtihad yang digunakan sebaiknya bersifat kolektif (jama'i). Hal ini dilakukan oleh para ahli yang tidak diragukan keahliannya dalam menggunakan bahasa Arab, mengetahui isi dan system hukum alquran, mengetahui hadits hukum dan segala perangkat ilmu hadis, memahami sumber hukum Islam dan cara menarik garis hukum, mengetahui qowa'idul fiqhiyyah, mengetahui rahasia dan tujuan hukum, jujur dan ikhlas, serta mengetahui ilmu antropologi dan sosiologi. Kelima, semua produk rekostruksi itu harus segera disosialisasikan kepada masyarakat umum. Keenam, khusus bagi kalangan pesantren, hal ini sejatinya menjadi kesadaran mendalam yang di follow-up-i dengan perubahan silabus tafsir dan qualitas fasilitatornya.

Epilog

Yang menjadi bahan pertanyaan orang adalah, kapan suatu perubahan sosial akan berhenti agar hukum pun dapat beristirahat sejenak sekedar melepas lelah. Dengan membaca pengalaman, manusia nampaknya tidak akan pernah meng-update hukum sejalan dengan perubahan sosial yang melingkupinya. 
Setiap waktu manusia harus terus terjaga memikirkan hukum baru yang tepat untuk suatu kondisi dan situasi baru di sekelilingnya. Ada hukum terkait produk teknologi baru, seperti produk handphone yang selalu dibawa orang kemana pun pergi, bahkan dibawa dalam peribadatan. Ada mobilitas warga yang menyesakkan lalu lintas, sehingga pemahaman jamak dan qashar harus direkonstruksi lagi. Ada lagi, karena penerapan hukum Syariah di beberapa otonomi daerah yang menerapkan 'Syariat Islam, masyarakat heboh karena wanita tidak boleh berkeliaran di malam hari. Dan masih banyak penerapan kasus sosial lain yang malah menghalangi aktivitas yang membebaskan dan mencerahkan. Apalagi masalah lama yang ditimbulkan oleh nafsu dan keserakahan manusia masih menjadi pekerjaan rumah yang harus diselesaikan. Masalah poligami, kawin siri, kawin kontrak, dll. itu harus diperdebatkan.

Lantaran itu nilai - nilai universal dalam hukum Islam perlu kita pahami dengan baik. Aluran sebagai sumber hukum hatus merupakan sumber inspirasi yang tidak pernah habis dan legitimasi tepat bagi segala semangat perubahan sosial. Peluang kearah itu terbuka lebar, sebab selain adanya ayat-ayat "dzanny" dan mutasyabihat segala hukum muamalah pun pada intinya terbuka untuk dikaji ulang.

Bahkan kesepakatan ulama di masa lalu (ijamak) sepertinya perlu terus kita kaji untuk mendapatkan semangat perubahan sosial yang diusung Alquran. Segala isu yang sudah ditempeli madzhab tertentu atau ulama tertentu, sejatinya harus terbuka untuk pemikiran baru yang semakin kontekstual. Mungkin menarik mengangkat contoh tentang qaul qodim (pendapat lama) Imam Syafi'iy ketika di Irak dan (qaul jadid) atau pendapat baru, ketika ulama besar ini pindah ke Mekkah.

Ada yang bilang sikap ini merupakan penafsiran yang kontekstual. Ada juga yang bilang itu kompromi agama dengan realitas. Ada orang yang nyeleneh bilang itu bid'ah. perbedaan pendapat ini sah-sah saja, asal disampaikan dengan santun dan tentu saja selama tidak keluar dari 5 (lima) buah tujuan disyariatkannya Islam yang dirumuskan Abu Ishaq As Syatibi yang disebut Maqasidus Syariah yang meliputi memelihara (1) akal fikiran, (2) memelihara agama, (3) memelihara jiwa, (4) memelihara harta, dan (5) memelihara keturunan. ***. 
i Daud Ali, Mohammad, H, Prof. H. SH, Hukum Islam, Cetakan kesebelas, raja Grafindo Persada, 41, 1994

ii Ibid, hal. 46

iii Lihat Mohammedanism, by H.A.R. GIBB, Home University Library.), PP 206, Geoffrey Cumberledge, Oxford University Pers, 1949, 5s

${ }^{\text {iv }}$ Daud Ali, Mohammad, H, Prof. H. SH, Loc Cit, hal. 87

${ }^{v}$ Lihat al-Asyhbah wan Nadza'ir hal. 66, al-Kharsyi 'ala Mukhtasar Khalil 5/149, Syarh al-Minhaj lil Baidhawi 2,751, Syarh Mukhtasar Raudhah 1/399, I'lam alMuwaqqi'in 1/344, dan jami'al-Ulum wal Hikam 2/166.

vi Daud Ali, Mohammad, Prof. H, SH., Hukum Islam: Pengantar Ilmu Hukum dan Tata Hukum Islam di Indonesia, Divisi Buku Indonesia, PT Raja Grafindo Persada, Jakarta, cetakan ke sebelas, (Jakarta, 2004), Hal. 85

vii Ibid, hal 85.

viii Charles Francis Potter, The Faith Men Live By, Kingswood, Suney, 1955, pg. 81 dalam "kekaguman Dunia Terhadap Islam" oleh. Hashem, Penerbit Pustaka, ITB, (Bandung, 1983) p. 44

ixixix Basanta Coomar Boose, Mohammedanism, Calcutta, 1931, pag. 4

${ }^{x}$ Daud Ali, Mohammad, Prof. H, SH., Op Cit, hal. 65

${ }^{x i}$ Republika, 31 mei 2013, WWW. Knowledge-Leader. Nett/2013/09/teks-al-qurandengan-realitas/... (Program Pasca Sarjana, Universitas Islam Negeri Sunan Gunung Jati, Bandung) 